\title{
Value-based stakeholder loyalty toward sport technology A case of the electronic body protector and scoring system in taekwondo events Lealtad de los stakeholders hacia la tecnología deportiva basada en el valor percibido
El caso del protector pectoral electrónico y del sistema de puntuación en eventos de taekwondo
}

\author{
Yong Jae Ko ${ }^{1}$, Yonghwan Chang ${ }^{1}$, Yong-Chae Rhee ${ }^{2}$, Joseph S Valacich ${ }^{3}$
} Youngjin Hur ${ }^{4}$ \& Chanmin Park ${ }^{1}$

$\mathbf{1}$ University of Florida. United States

$\mathbf{2}$ Washington State University. United States

3 University of Arizona. United States

4 University of Central Missouri. United States

\begin{abstract}
Only a few studies have examined issues related to sport stakeholders' (e.g., athletes', spectators', and coaches') perceived value of technology products and its influence on the purchase intention of sport technology. The model of value-based stakeholders' loyalty toward sport technology (MVLST) is offered to inform customer purchase intentions of technology-based products by proposing theoretical relationships between perceived value, brand attitude, and purchase intention. The MVLST leverages core aspects of the technology acceptance model (TAM) and salient product attributes as quality, price, and innovativeness to develop the perceived value of sport technology (PVST). To test the theoretical relationships proposed in MVLST, a structural equation model was performed. Finally, multi-group SEM was employed to examine the moderating effect of consumer involvement. A total of 341 useful cases were collected from key stakeholders (e.g., spectators, coaches, and athletes) attending the 2010 US Open Taekwondo Championship; the technology-based product assessed by these survey participants was the electronic body protector and scoring system. The results of this analysis demonstrate that: (i) Usefulness, quality, and price are important value dimensions for attitude; (ii) conative loyalty (i.e., purchase intention) toward a sport technology occurs as consumers develop positive value perceptions and attitude toward the product; and (iii) the purchase intention of high vs. low involvement groups is dissimilarly influenced by the proposed value dimensions. From a theoretical perspective, the current study sheds light on the importance of attitude as a mediating variable and involvement as a moderating variable.
\end{abstract}

Key words: sport technology; value perception; taekwondo event; TAM; scale development.

\section{Resumen}

Hasta el momento, solo unos pocos estudios han examinado temas relacionados con el valor percibido de stakeholders (ej. atletas, espectadores, y entrenadores) sobre productos tecnológicos y su influencia en las intenciones de compra de tecnología deportiva. El modelo de lealtad de los stakeholders basado en el valor percibido hacia la tecnología deportiva (MVLST) es presentado, en aras de mejorar el conocimiento sobre la intención de compra de productos tecnológicos en deporte, proponiendo relaciones teóricas entre el valor percibido, la actitud hacia la marca y las intenciones de compra. Este modelo aprovecha aspectos centrales del modelo de aceptación de la tecnología (TAM), junto con la calidad, la innovación y el precio, para desarrollar el valor percibido de la tecnología deportiva (PVST). Para probar las relaciones teóricas propuestas en MVLST, se implementó un análisis a través de un modelo de ecuaciones estructurales. Finalmente, el análisis multi-grupo SEM examinó el efecto moderador de la participación de consumidor. Un total de 341 casos útiles fueron recogidos de diferentes grupos de interés (ej. espectadores, entrenadores, atletas) que asistieron al US Open Taekwondo Championship en 2010. Los productos tecnológicos evaluados fueron el protector pectoral electrónico y el sistema de puntuación. Los resultados del análisis sugieren que: (i) la utilidad, la calidad, y el precio forman dimensiones de valor importantes para la actitud, (ii) la lealtad conativa, es decir, la intención de compra hacia productos deportivos tecnológicos ocurre en la medida en que los consumidores desarrollan percepciones de valor y actitudes positivas hacia el producto, y (iii) la intención de compra de los grupos de alta o baja participación está influenciada por las dimensiones de valor propuestas. Desde una perspectiva teórica, este estudio muestra la importancia de la actitud como variable mediadora y la participación como una variable moderadora.

Palabras clave: tecnología deportiva; percepción del valor; evento de taekwondo; modelo de aceptación de la tecnología; desarrollo de escala.

Correspondence/correspondencia: Yong Jae Ko

Department of Tourism, Recreation, and Sport Management at the University of Florida. United States Email: yongko@ufl.edu 
Ko, J. Y.; Chang, Y.; Rhee, Y.; Valacich, J. S.; Hur, Y.; Park, C. (2014). Value-based stakeholder loyalty toward sport technology A case of the electronic body protector and scoring system in taekwondo events. RICYDE. Revista internacional de ciencias del deporte, 35(10), 46-62 http://dx.doi.org/10.5232/ricyde2014.03504

\section{Introduction}

$I^{\prime}$ n highly competitive markets, developing consumer brand loyalty is often a firm's top marketing priority because of the many benefits brand loyalty can generate. Benefits include higher sales volume, profit margins, and market share as well as lower customer acquisition costs and higher entry barriers for competitors (Brexendorf, Mühlmeier, Tomczak, \& Eisend, 2010; Knox \& Walker, 2001). Consequently, many firms make great efforts to offer the best-possible products and services, often leveraging innovative technology. For example, in the mobile internet industry, handset manufacturers use innovative concepts (e.g., merging of devices and capabilities such as GPS navigation, browsing, etc.) and emerging technologies (e.g., 4G networks) as a means for attracting new customers and gaining their loyalty. Likewise, the National Football League revamped and added new elements to its nfl.com website, including redesigned Game Center pages with 3D-type depth, a sharply expanded social media and community section, and a bulked-up content subscription area providing full-length online game replays (Fisher, 2009). Sport leagues are adopting innovative technology products as a means to reduce scoring biases by officials, to improve game operations, or to improve the spectator experience (e.g., Hawk-eye sensors in tennis and cricket matches, goal-line indicator technology in football, and electronic scoring systems in fencing and taekwondo tournaments to name a few).

At the same time, it is a significant challenge for marketers to fully understand consumers' decision making processes when adopting a broad variety of technology products. Both academicians and practitioners have attempted to identify the most prominent sources of brand loyalty in order to prescribe effective marketing strategies. However, consumers' successful adoption of new technology products relies on how consumers perceive the value and quality of the product (Zhang \& Prybutok, 2005). Consequently, a basic assumption in examining consumer behavior is to understand the importance of value maximization (Kim, Chan, \& Gupta, 2007). In other words, before consumers accept and ultimately become loyal to a new technology product, they first pursue the highest level of "what I receive" (e.g., product and service quality), in comparison to "what I give" (e.g., price; Zeithaml, 1988). That is, they expect their perception of the give-take balance to be in their favor. Key stakeholders' (e.g., spectators, competitors, referees, and the media) loyalty formation toward the newly adopted sport technology-based products has not been explored from the value maximization perspective.

Although previous studies have found that consumer loyalty to a brand can be generated by delivering superior value derived from excellent product and service quality (Parasuraman \& Grewal, 2000; Yang \& Peterson, 2004), a more comprehensive and systematic analysis of consumers' brand loyalty formation is needed in the context of high-tech sport product consumption behavior. As of yet, however, this issue has not receive attention from scholars in the field of sport management and marketing. Accordingly, the main purposes of this 
Ko, J. Y.; Chang, Y.; Rhee, Y.; Valacich, J. S.; Hur, Y.; Park, C. (2014). Value-based stakeholder loyalty toward sport technology A case of the electronic body protector and scoring system in taekwondo events. RICYDE. Revista internacional de ciencias del deporte, 35(10), 46-62 http://dx.doi.org/10.5232/ricyde2014.03504

research were: (i) to identify important factors of perceived value of sport technology (PVST) in predicting attitudinal and conative loyalty (purchase intention), and (ii) to examine the moderating effect of consumer involvement in the relationships between value dimensions and purchase intention. Results from this study should inform marketers of the interplay between perceived value dimensions, brand attitude, and loyalty. Furthermore, the results should provide justification for further investments into sport technology to better meet the needs of their consumers. This study also aids future research by providing a foundation for ongoing investigations of high-tech sport products and consumption behavior.

\section{Theoretical Background}

In psychology, values are conceptions of the desirable and generally classified into two approaches: preferences and principles. Existing value studies (e.g., Parks \& Guay, 2009) suggest that values as preferences are more closely related to attitude rather than behavior. For example, someone who values fairness in sporting events would be more satisfied with an unbiased electronic scoring system in Taekwondo events. Similarly, by focusing on interactive relativistic preferences, Holbrook (2006) defined customer value as subjective preferences based on an individual's situation-specific comparisons of one object with another. The author highlighted that products should perform in a way that provides the relevant value-creating experiences.

On the other hand, values as principles guide individuals' behavior (Parks \& Guay, 2009). For example, an individual who values fairness would likely believe that all sporting events ought to have electronic scoring systems, while an individual who values tradition of sporting events may refuse those devices. Therefore, values as principles more directly impact motivation and consumption behaviors as well as serve as guiding principles about how individuals ought to behave (Schwartz, 1994).

The expectancy-value model (Fishbein \& Ajzen, 1975; Johnson, Gustafsson, Andreassen, Lervik, \& Cha, 2001) was applied as a theoretical foundation for this study. This theory suggests that a person's behavior is determined by his/her expectations (beliefs) and evaluations (Palmgreen, 1984). A number of studies adapted this theory to test the causal relationships between expectations, evaluations, and behaviors (Lim \& Dubinsky, 2004; Smith \& Vogt, 1995). For example, Lim and Dubinsky (2004) found that a positive affect toward a commercial website is developed according to consumers' perceived characteristics of the website (e.g., high quality information and trustful transaction system). Based on the expectancy-value model to the high-tech product consumption context, it is suggested that consumers' cognitive beliefs about a product influences their attitude toward a product brand. Positive attitude, in turn, influences the likelihood that a consumer repurchases the product in the future. Based on this understanding, and by following the research streams on consumer value (Sánchez-Fernandez, Iniesta-Bonillo, \& Holbrook, 2009), we consider economic and utilitarian aspects of values as principles. 
Ko, J. Y.; Chang, Y.; Rhee, Y.; Valacich, J. S.; Hur, Y.; Park, C. (2014). Value-based stakeholder loyalty toward sport technology A case of the electronic body protector and scoring system in taekwondo events. RICYDE. Revista internacional de ciencias del deporte, 35(10), 46-62 http://dx.doi.org/10.5232/ricyde2014.03504

The current study also utilized core beliefs in the technology acceptance model (TAM: Davis, 1989; Davis, Bagozzi, \& Warshaw, 1989) to examine the relationships between perceived value, brand attitude, and behavioral intention. Originally, TAM was proposed by Davis (1989) based on the theory of reasoned action (TRA: Fishbein \& Ajzen, 1975) and has become one of the dominant frameworks to explain end users' acceptance of technology-centered, computer-based systems and products; its popularity has been driven by it explanatory power and parsimonious application (Venkatesh \& Davis, 2000). Two of TAM's core dimensions are Ease of Use and Usefulness.

\section{A Research Model}

The proposed research model delineates the theoretical relationships between perceived value and two significant consumer variables: attitude and conative loyalty (purchase intention). Figure 1 illustrates the hypothesized relationships among the research variables. When consumers accept and ultimately become loyal to a newly emerging high-tech product, they first reflect on their perceptions of the give-take balance because value maximization is one of the most common and basic assumptions in the decision making process. Therefore, we developed a value framework in the context of technology products.

In building a model of value-based stakeholder loyalty toward sport technology (MVLST), two major dimensions were conceptualized to influence stakeholders' perceived product values. They include the core aspects of TAM (i.e., usefulness and ease of use) and three key product (high-technology) value attributes (i.e., quality, price, and innovativeness). Moreover, it is proposed that consumers' value perceptions toward technology products directly influence their attitudes and intentions to purchase the product brand. Heightened levels of perceived value and positive attitude toward the brand were hypothesized to positively related with purchase intention. Consumers' value perceptions toward a sport technology directly influence their brand attitudes. In the following section, specific dimensions of perceived value and hypothesized relationships among the key constructs are presented.

\section{Perceived value dimensions}

Through an exploratory study, Zeithaml (1988) identified four patterns of value including (a) low price, (b) whatever I want in a product, (c) quality I get for the price I pay, and (d) what I get for what I give. By integrating these four different aspects, Zeithaml (1988) defined perceived value as "the consumer's overall assessment of the utility of a product based on perceptions of what is received and what is given" (p.14). Past research identified that consumers' perceived value is an important predictor of consumers' loyalty formation (Dodds, Monroe, \& Grewal, 1991; Patterson \& Spreng, 1997). In this study, perceived value is a higher-order latent construct formed by five distinct value constructs-namely, usefulness (utilitarian), ease of use (utilitarian), quality (utilitarian), price (economic), and 
Ko, J. Y.; Chang, Y.; Rhee, Y.; Valacich, J. S.; Hur, Y.; Park, C. (2014). Value-based stakeholder loyalty toward sport technology A case of the electronic body protector and scoring system in taekwondo events. RICYDE. Revista internacional de ciencias del deporte, 35(10), 46-62 http://dx.doi.org/10.5232/ricyde2014.03504

innovativeness (utilitarian). The following section addresses each of the value dimensions of high-tech products.

Perceived usefulness and value. Perceived usefulness is defined as the degree to which the consumer believes that using the product would fulfill the certain purpose of consuming it. The relationship between perceived usefulness and perceived value has been examined in several settings. For instance, Kim et al. (2007) examined this relationship and found a positive effect from perceived usefulness to perceived value when adopting mobile Internet. Chu and Lu (2007) also supported this relationship when purchasing online music. Utilitarian (e.g., useful information) experience has been found to have a positive relationship to perceived value when visiting a brand manufacturer's web site (Steenkamp \& Geyskens, 2006). Applying this logic with the current study, it suggests that a high-tech product would be perceived as being useful, and that by being useful (e.g., improving the fairness of a competition), it also provides value.

Perceived ease of use and value. Perceived ease of use is one of the core constructs of TAM (Davis, 1989; Davis et al., 1989). In the current study, ease of use refers to the degree to which the consumer believes that using a high-tech product would be free of effort. Consequently, it follows that if a high-tech product is perceived as being easy-to-use, it is intuitive that it will also increase its perceived value.

Product quality, price and value. Zeithaml (1988) argued that perceived value is defined as the "consumer's overall assessment of the utility of a product based on perceptions of what is received and what is given" (p. 14). Note that this definition embraces the constructs, quality and price, as key elements of the value perception. Product quality refers to the consumer's judgment about a product's overall superiority or excellence. Whereas, price refers to what is given up or sacrificed in order to obtain a product (Zeithaml, 1988). For example, when consumers encounter a purchase decision, they pursue the highest "get" components (e.g., superior quality, convenience, and self-esteem) and compare them to the "give" components (e.g., expended money, time and effort). Moreover, numerous retailing and online shopping empirical studies have found that product quality perceptions positively influence perceived value (Bauer, Falk, \& Hammerschmidt, 2006). Similarly, quality and price perceptions have been found to significantly influence value perception (Zeithaml, 1988). Therefore, it follows that if a high-tech product is perceived to have superior quality and fairly priced, it will also be perceived to have high value.

Innovativeness and perceived value. Innovativeness is proposed as one of the critical indicators of value perception in the context of high-tech product consumption. To be successful in the market, new technology products often use cutting-edge technology or provide new capabilities (Gatignon \& Xuereb, 1997). Highly innovative products are often perceived as being more valuable, often yielding premium pricing (Ingenbleek, Frambach, \& Verhallen, 2010). Innovativeness is driven by many factors. For instance, some companies (e.g., Apple computers) are viewed as being highly innovative as a brand. In addition to the 
Ko, J. Y.; Chang, Y.; Rhee, Y.; Valacich, J. S.; Hur, Y.; Park, C. (2014). Value-based stakeholder loyalty toward sport technology A case of the electronic body protector and scoring system in taekwondo events. RICYDE. Revista internacional de ciencias del deporte, 35(10), 46-62 http://dx.doi.org/10.5232/ricyde2014.03504

perceptions of the brand, product capabilities and the underlying technologies employed can drive innovation perceptions. Consequently, in the context of the current study, consumer perceptions of innovativeness of the high-tech product should also influence its perceived value.

\section{Hypothesis development}

Based on this review, three hypotheses associated with a research model are proposed. These hypotheses focus on the interrelationships among perceived value dimensions, brand attitude, and purchase intention. In addition, the moderating effects of sport involvement in the relationships between perceived value dimensions and purchase intention is also examined.

Prior consumer behavior research suggests that loyalty-i.e., a deeply held commitment to rebuy or re-patronize a product or service in the future-evolves in stages (cognitive, affective, conative, and behavioral level; Oliver, 1999). Affective or attitudinal loyalty, refers to favorable attitude toward a brand. Attitude is defined as "a learned predisposition to respond in a consistently favorable manner with respect to a given object" (Fishbein \& Ajzen, 1975 , p. 6). The primary goal of brand management is to create a positive attitude toward a brand. Conative loyalty refers to an intention to continue to purchase a particular product in the future. Purchase intention is proposed as the central dependent variable, and is influenced by consumers' value perceptions and attitude toward a brand. Action loyalty, reflects a stage where the consumer is willing to go out of his/her way to purchase a product. According to Ajzen (1991, 2001), people behave according to their intentions and perceptions of control over their behavior; intentions are affected by attitudes toward the behavior, perceptions of behavioral control, and subjective norms. A number of studies support the assertion that intentions play an important role in guiding actual behavior (Ajzen, 2001; Kendzierski \& Whitaker, 1997). As such, intention to purchase the brand has been included as the dependent variable.

Prior research suggests that consumers' perceived value is an important predictor of consumers' loyalty formation based on market share in the industry (Baker, 1990; Dodds et al., 1991). For example, Dodds et al. (1991) explored consumers' willingness to purchase and attitude, hypothesizing that both were higher when consumers derived maximized value from a brand. Similarly, according to Sweeney and Soutar (2001), when consumers perceive higher value with a brand, their attitudes toward the brand tend to be more favorable than their attitude toward perceived lower-value brands. Both perceived value and brand attitude were hypothesized to be positively associated with purchase intention. This suggests the following:

\section{H1. Perceived value dimensions are positively related with brand attitude.}

H2. Perceived value dimensions are positively related with purchase intention.

Prior research has highlighted the importance of measuring attitudes toward a firm or its brand when assessing the outcomes of brand management studies (Priester, Nayakankuppam, 
Ko, J. Y.; Chang, Y.; Rhee, Y.; Valacich, J. S.; Hur, Y.; Park, C. (2014). Value-based stakeholder loyalty toward sport technology A case of the electronic body protector and scoring system in taekwondo events. RICYDE. Revista internacional de ciencias del deporte, 35(10), 46-62 http://dx.doi.org/10.5232/ricyde2014.03504

Fleming, \& Godek, 2004). Copeland (1923) suggested that a buyer's extreme attitude toward a specific brand results in a unique effect on buyer behavior. Brand attitude has been found to be an important predictor of behavioral intentions (Burton, Lichtenstein, Netemeyer, \& Garretson, 1998). Similarly, Keller (1993) argued that consumers with a favorable brand attitude tend to be more agreeable to paying premium prices for the brand. Therefore, consumers' attitudes toward a specific brand are likely to be positively related to their intentions to purchase the brand. This suggests:

\section{H3. Brand attitude is positively related with purchase intention.}

Clearly, there are many stages of brand loyalty, and different types of products, context, and consumers will influence this evolution through these stages. In other words, we focus on a consumer's general assessment of a product, acknowledging that some consumers may vary in their current loyalty toward the high-tech product, and that these differences may create some variance in consumption decision. In sum, following Oliver's (1999) conceptualization, we defined consumers' high-tech brand loyalty as a staged multi-faceted and stages construct. Additionally, consumers sport involvement may play an important role in predicting purchase intention of sport technology. As such a research question is proposed.

Q1. Does sport involvement play an important role in this relationships between the perceived value of sport technology (PVST) and purchase intention?

\section{Method}

\section{Measures}

The selection of the measures utilized in the study followed a three-step process. First, the extant scales of focal constructs were collected from the relevant literature. Second, the scales were assessed by a panel of scholars who had expertise in technology and marketing. Several items in the scales were dropped or revised based on the feedback from the panel of scholars. After the expert review, a total of 27 items were retained to measure the nine constructs. Each construct was measured using multiple items and a 7-point Likert-type scale (i.e., $1=$ "strongly disagree" to 7 = "strongly agree").

Items of Ease of Use (4 items) and Usefulness (4 items) were adapted from Davis's (1989) and Davis et al.'s (1992) studies. We measured Ease of Use using such items as "I would find this product easy to use." A measure of Usefulness included "Using this product would improve my performance in an (activity)."

Product quality refers to consumers' subjective judgments about a brand's general superiority (Boulding \& Kirmani, 1993; Zeithaml, 1988); three product quality items were modified and adapted from existing scales (Dodds et al., 1991). Price refers to what is given up or sacrificed to obtain a product it was measured by three items adapted from existing scales (Sheth, Newman, \& Gross, 1991; Sweeney \& Soutar, 2001; Zeithaml, 1988). To measure 
Ko, J. Y.; Chang, Y.; Rhee, Y.; Valacich, J. S.; Hur, Y.; Park, C. (2014). Value-based stakeholder loyalty toward sport technology A case of the electronic body protector and scoring system in taekwondo events. RICYDE. Revista internacional de ciencias del deporte, 35(10), 46-62 http://dx.doi.org/10.5232/ricyde2014.03504

product innovativeness, items that reflected a firm's existing marketing resources, technological resources, skills, knowledge, capabilities, or strategies were adapted from prior scales (Brown \& Dacin, 1997; Capon, Farley, Hulbert, \& Lehmann, 1992; Sen \& Bhattacharya, 2001). Customer brand attitude (3 items) and purchase intention (3 items) were measured by multiple semantic-type scales (Bagozzi, Baumgartner, \& Yi, 1992; Petrova \& Cialdini, 2005; Yi, 1990) including, "My attitude toward this product is: Bad-Good, Unfavorable-Favorable, and Unsatisfactory-Satisfactory," and "My future intention to purchase this product is: Impossible-Possible, Very unlikely-Very likely, and Improbable-Probable."

\section{Sample and data collection}

The target sample of the study was key stakeholders (athletes, coaches, referees, and spectators) of the US Open Taekwondo Championship. The sport technology examined in this research was the electronic body protector and scoring system was recently developed and adapted by the World Taekwondo Federation (WTF) and many WTF-sanctioned events, including the Olympics.

The survey questionnaire was administered to spectators, athletes, coaches, and referees who attended the event between June 29 and July 4, 2010, in Orlando, Florida. Data were collected at the Orange County Convention Center during the championship (6 days). Questionnaires were distributed to a convenience sample of 800 spectators who were intercepted individually as they entered the event through the two main gates. Members of the research team were also stationed at a booth assigned by the tournament staff. Coaches and referees participated in the survey during their lunch and coach/referee seminars.

The research assistants explained that involvement in the study was voluntary and thereafter distributed the informed consent. This form was completed by all participants in compliance with Institutional Review Board protocol. After the initial contact, the participants were given a brief explanation of the purpose of the research and instructions about how to properly fill out the survey. On average, it took approximately 10 minutes for the participants to complete the questionnaire. No compensation was provided to the survey participants.

A total of 650 completed questionnaires were returned ( $81 \%$ response rate), of which 341 useful cases were included in data analysis. Overall, we feel confident that the results contained in this study are reflective of the perceptions and attitudes of those attendees at the event. In terms of sample characteristics, slightly more spectators were male $(n=227 ; 66 \%)$ while $34 \%$ were female $(n=114)$. The average age of the visitors was 32.4 years, ranging from 16 to 78 years old. In terms of ethnicity, $47 \%$ of the respondents were self-identified as Caucasian. The largest visible minority group was Asian American (23.4\%; $n=78)$, followed by Hispanic $(16 \% ; n=54)$, African-American $(8 \% ; n=27)$, and Native American $(1.3 \% ; n=$ 4). In terms of status/affiliation, the largest group was spectators $(43 \% ; n=146)$ followed by athletes $(36 \% ; n=122)$, coaches $(19 \% ; n=66)$ and officials $(2 \% ; n=7)$. 
Ko, J. Y.; Chang, Y.; Rhee, Y.; Valacich, J. S.; Hur, Y.; Park, C. (2014). Value-based stakeholder loyalty toward sport technology A case of the electronic body protector and scoring system in taekwondo events. RICYDE. Revista internacional de ciencias del deporte, 35(10), 46-62 http://dx.doi.org/10.5232/ricyde2014.03504

\section{Data analysis}

Before testing the proposed model and research hypotheses, we analyzed descriptive statistics and psychometric properties of the measurement scale. A series of structural equation models was performed using the package lavaan (Rosseel, 2012) in R (R Development Core Team, 2012). A structural equation model was conducted to test research hypotheses and the psychometric properties of the proposed measures. Additionally, a multi-group SEM was conducted to examine the moderating effect of consumer involvement.

\section{Results}

\section{Data screening and test of assumptions}

No out-of-range scores were found in the data set. The linearity scatter plots showed that there was no evidence of non-ignorable data patterns. The skewness ranged from -.47 .33 and kurtosis ranged from $-1.04 \sim-.23$, which indicates normality in the distribution of the data (Hair, et al., 2005). To test multicollinearity of the data under multi-factor circumstances, a linear regression was performed with one factor set as a dependent variable. Results $(\mathrm{R} 2=.67$; Tolerance $=.19 \sim .48 ; \mathrm{VIF}=2.1 \sim 4.6)$ indicate that extreme multicollinearity was not detected (Kline, 2005).

\section{Test of research hypotheses}

A simultaneous equation model was performed to access the fit statistics and standard errors of the parameter statistics of the data. The proposed model did not achieve acceptable fit to the data as chi-square was significant; $\chi^{2}=874.215(d f=356, p<.001)$. We assume that this lack of fit may stem from the large sample size since we found no substantial improvement in chi-square fit after careful modifications of the research model based on the matrix of residuals and the corresponding modification indices (LM and Wald tests). Nonetheless, further analysis and discussion of these results was continued because of the theoretical and practical contributions of the current study within a novel context as suggested by Barrett (2007).

The direct paths from Usefulness $(\beta=.496, p<.001)$, Quality $(\beta=.275, p<.001)$, and Price $(\beta=.149, p=.035)$ to Attitude were significant. In addition, the direct paths from Price $(\beta=$ $.224, p<.001)$ and Attitude $(\beta=.617, p<.001)$ to Purchase Intention were significant. A summary of results is depicted in Figure 1. 
Ko, J. Y.; Chang, Y.; Rhee, Y.; Valacich, J. S.; Hur, Y.; Park, C. (2014). Value-based stakeholder loyalty toward sport technology A case of the electronic body protector and scoring system in taekwondo events. RICYDE. Revista internacional de ciencias del deporte, 35(10), 46-62 http://dx.doi.org/10.5232/ricyde2014.03504

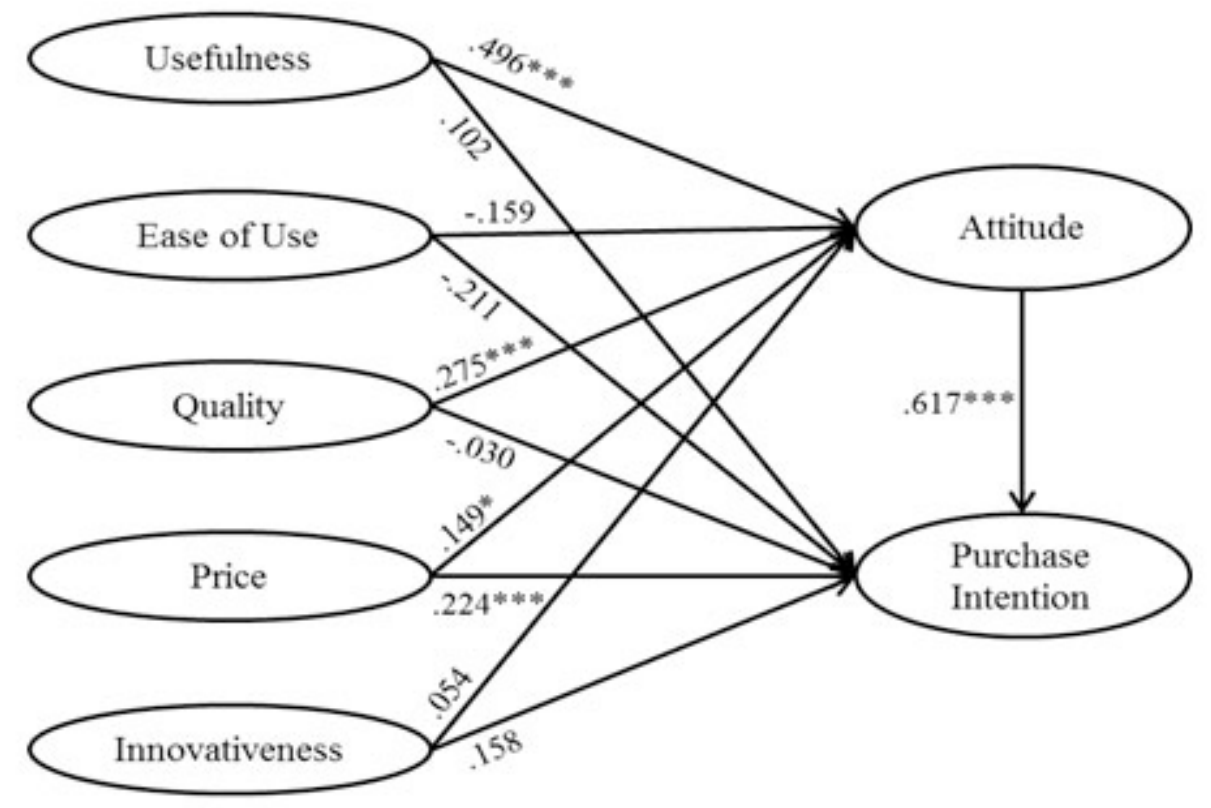

${ }^{* *} p<.01 . * p<.05$.

Figure 1. Value-based loyalty formation model and standardized loadings and coefficients $[\mathrm{CFI}=.94$;

$$
\text { RMSEA }=.06 ; \text { SRMR }=.04]
$$

\section{Test of moderating effect}

To estimate the moderating effects of involvement level between the factors of perceived value of sport technology (PVST) and purchase intention, the participants were classified into two independent groups based on the number of Taekwondo tournament participation in the past year (i.e., equal or less than 2 times, $n=217$; and greater than 3 times, $n=124$ ). We fitted the multiple-group structural equation model shown in Figure 2 using maximum likelihood estimation. For the multiple-group SEM fit, the chi-square was significant $\left(\chi^{2}=\right.$ 1198.244, $d f=568, p<.001)$. Again, despite this poor fit, further analysis and discussion in justified due to the theoretical and practical implications as documented above.

To examine whether the factor structure is statistically equivalent across the groups, a series of hierarchically nested models were tested following established procedures (e.g., Netemeyer, Bearden, \& Sharma, 2003). The hierarchy began with the least restrictive model (i.e., configural invariance model) where no constraints were placed, indicating the same pattern of fixed and nonfixed parameters across groups. This model was used as a baseline to compare with subsequent models in the hierarchy. For the second level of invariance test, all of the factor loadings were constrained to be equal across groups. This level of invariance was nested within the configural invariance model. The results showed that the chi-square difference was not significant, $x_{\Delta}^{2}(\Delta d f=40)=28.99, p=.901$, indicating invariant factor 
Ko, J. Y.; Chang, Y.; Rhee, Y.; Valacich, J. S.; Hur, Y.; Park, C. (2014). Value-based stakeholder loyalty toward sport technology A case of the electronic body protector and scoring system in taekwondo events. RICYDE. Revista internacional de ciencias del deporte, 35(10), 46-62 http://dx.doi.org/10.5232/ricyde2014.03504

loadings across groups. For the third level of invariance test, all of the factor loadings and intercepts were constrained to be equal across groups. This level of factorial invariance was nested within Model 2. The results showed that the chi-square difference was not significant, $x_{\Delta}^{2}(\Delta d f=80)=73.656, p=.678$, indicating invariant factor loadings and intercepts across groups. In sum, the results of the measurement invariance test suggest that there was consistency in response patterns to items across groups (Netemeyer et al., 2003).

Parameter estimates for the model are depicted in Figure 2. Specifically, for high-involvement group, usefulness $(\beta=.696, p=.001)$ and price $(\beta=.535, p=.003)$ of the product significantly influenced their purchase intention. For low-involvement group, usefulness $(\beta=.77, p=.034)$, quality $(\beta=.467, p=.014)$, and price $(\beta=.402, p=.006)$ of the product significantly influenced their purchase intention.

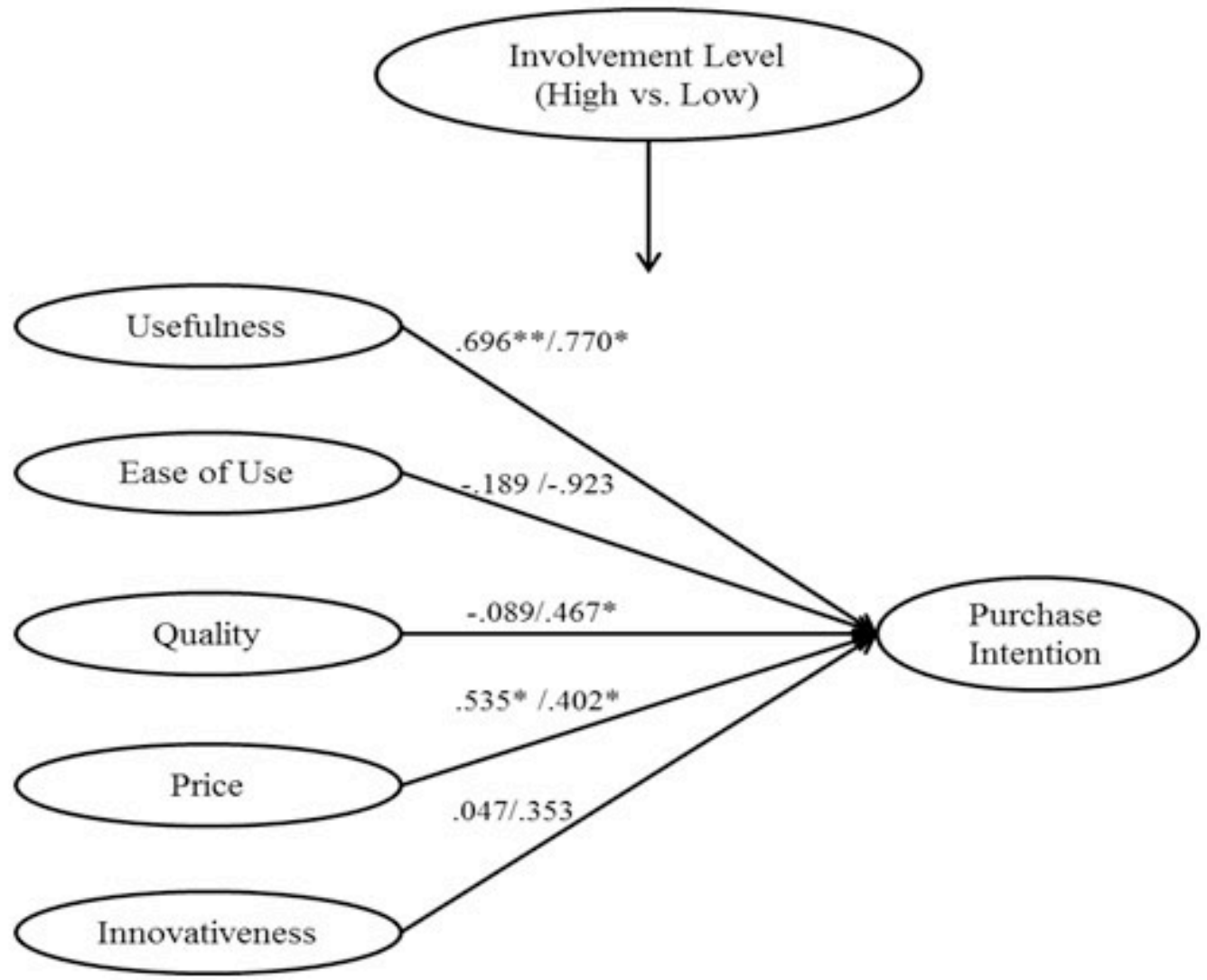

Note: Structural coefficients for high involvement group/structural coefficient for low involvement group

${ }^{* * *} p<.001 .{ }^{* *} p<.01 .{ }^{*} p<.05$.

Figure 2. Results of multi-group SEM $[\mathrm{CFI}=.91 ; \mathrm{RMSEA}=.08 ; \mathrm{SRMR}=.06]$ 
Ko, J. Y.; Chang, Y.; Rhee, Y.; Valacich, J. S.; Hur, Y.; Park, C. (2014). Value-based stakeholder loyalty toward sport technology A case of the electronic body protector and scoring system in taekwondo events. RICYDE. Revista internacional de ciencias del deporte, 35(10), 46-62 http://dx.doi.org/10.5232/ricyde2014.03504

\section{Discussion}

\section{Theoretical Implications}

The purposes of this research were: (i) to identify significant value dimension when predicting consumers' attitudinal and behavioral loyalty toward a sport technology product, and (ii) to examine the moderating role of sport involvement. To accomplish the purposes of the research, a series of analyses were performed. First, the authors developed a scale to capture stakeholders' perceived value for technology-based products by combining core aspects of the technology acceptance model (i.e., usefulness and ease of use) and salient product attributes (i.e., product quality, price, and product innovativeness). The results of a simultaneous equation model suggest that the developed measurement scale did not statistically work well. However, based on theoretical and practical standpoints, the TAM itself is a well-established model and the two dimensions are conceptually unique from each other. Overall, it would be deemed reasonable to use them to test the MVLST theoretically and practically although caution should be used when interpreting the results of the current study considering the model fit statistics.

In the main model test, the direct paths from Usefulness, Quality, and Price to Attitude were significant. In addition, the direct paths from Price and Attitude to Purchase Intention were significant. From a theoretical perspective, the current study sheds light on the importance of attitude, a construct that has gradually been omitted from technology adoption studies. Most notably, attitude toward using technology-based products almost fully mediates the effect of perceived value on intention to purchase technology-based products. That is, the effect of perceived value is no longer significant in directly explaining behavioral intention, which is contrary to the findings of many technology adoption studies (e.g., Agarwal \& Prasad, 1999; Davis et al., 1989; Gefen \& Straub, 2000; Venkatesh, 2000; Venkatesh \& Davis, 2000). This finding alerts researchers to be cautious in removing attitude from their models when examining technology acceptance by individual consumers.

The relationship among the three constructs in this model follows the footsteps of a classic relationship introduced by Fishbein and Ajzen (1975), which includes belief, attitude, intention, and behavior relationship. However, the hypotheses based on sport technology products have, to our knowledge, not been previously verified.

Additionally, multi-group SEM indicates that consumer involvement plays a significant role as a moderator. Specifically, the results of the current study show that for individuals who were highly involved in the sporting event, usefulness and price were found to be the significant predictors of purchase intention. Besides usefulness and price, quality of the product was an additional key factor in predicting the purchase intentions of individuals who have a low level of involvement. Against this background, the current study replicates and extends the classic relationship within the context of technology-based products. 
Ko, J. Y.; Chang, Y.; Rhee, Y.; Valacich, J. S.; Hur, Y.; Park, C. (2014). Value-based stakeholder loyalty toward sport technology A case of the electronic body protector and scoring system in taekwondo events. RICYDE. Revista internacional de ciencias del deporte, 35(10), 46-62 http://dx.doi.org/10.5232/ricyde2014.03504

\section{Managerial Implications}

Since this innovative technology product was adapted for the 2012 London Olympics, Taekwondo became the second Olympic sport using the electronic body protector and scoring system, along with fencing. The product includes a foam-based chest protector that is commonly used in the industry as protective gear along with embedded electronic sensors that automatically record and transmit the number of landed blows by an opponent. This innovative system provides many benefits including real-time scoring, less bias in outcomes, and enhanced enjoyment for spectators. Taekwondo is an Olympic sport and has had a rash of judging controversies in the past (Chi, 2005; Ko et al., 2011). It is the hope that this new scoring system will provide the best-possible judging tool to enhance fairness and excitement of Taekwondo events.

Nonetheless, acceptance of this new technology at the local level needs to be carefully examined. It is very important to develop systematic information about the key stakeholders including administrators, athletes, coaches, and referees and their decision making process. The results of this study indicate that consumers' perceived values of this technology product are very important to form positive attitude and predict their purchase decision. Additionally, specific value dimensions are not equally important for the stakeholders. Perceived usefulness and price were found to be extremely important for highly involved Taekwondo practitioners while perceived usefulness, price, and product quality are important aspects of value for the low involvement group.

The results of the multiple group SEM analysis may provide practical implications to marketers in segmenting and targeting a market since the two groups are dissimilarly influenced by the proposed value dimensions. In sum, it is recommended that managers need to develop and implement highly customized promotional and marketing strategies targeted for the two different customer groups.

\section{Conclusion and Future Research}

In general, value perceptions of the technology product were found to be important for general customers in increasing their acceptance and purchase of the products. This study, along with previous research, should be regarded as one of the many steps necessary for understanding sport consumers' use of technology-based products. Future studies may investigate the other major antecedents of attitude strength in conjunction with the TAM to clearly understand their consumption behavior. Maybe, consumer satisfaction can be incorporated as an alternative of attitude? Additionally, while our investigation occurred within a specific sport industry utilizing a specific high-tech innovation, we believe there is a fruitful research opportunity to replicate our study in differing contexts. Such replications will not only provide external validity to the core aspects of our conceptual model but also help define its conceptual boundaries. Clearly, a host of research opportunities remain. 
Ko, J. Y.; Chang, Y.; Rhee, Y.; Valacich, J. S.; Hur, Y.; Park, C. (2014). Value-based stakeholder loyalty toward sport technology A case of the electronic body protector and scoring system in taekwondo events. RICYDE. Revista internacional de ciencias del deporte, 35(10), 46-62 http://dx.doi.org/10.5232/ricyde2014.03504

\section{Acknowledgement}

This research is supported by a research grant from LaJust Sports.

\section{References}

Agarwal, R., \& Prasad, J. (1999). Are individual differences germane to the acceptance of new information technologies? Decision Sciences, 30, 361-391.

Ajzen, I. (1991). The theory of planned behavior. Organizational Behavior and Human Decision Process, 50: 179-211.

Ajzen, I. (2001). Nature and Operation of Attitudes. Annual Review of Psychology, 52, 27-58.

Bagozzi, R. P.; Baumgartner, H., \& Yi, Y. (1992). State versus action orientation and the theory of reasoned action: An application to coupon usage. Journal Consumer Research, 18, 505-518.

Baker, W. E. (1990). Market networks and corporate behavior. American Journal of Sociology, 96, 589-625.

Barrett, P. (2007). Structural equation modeling: Adjudging model fit. Personality and Individual Differences, 42, 815-824.

Bauer, H.; Falk, T., \& Hammerschmidt, M. (2006). eTransQual: A transaction process-based approach for capturing service quality in online shopping. Journal of Business Research, 59, 866-875.

Boulding, W., \& Kirmani, A. (1993). A consumer-side experimental examination of signaling theory: Do consumers perceive warranties as signals of quality? Journal of Consumer Research, 20, 111-123.

Brexendorf, O. T.; Mühlmeier, S.; Tomczak, T., \& Eisend, M. (2010). The Impact of sales encounters on brand loyalty. Journal of Business Research, 63, 1148-1155.

Brown, T. J., \& Dacin, P. A. (1997). The company and the product: Corporate associations and consumer product responses. Journal of marketing, 61, 68-84.

Burton, S.; Lichtenstein, D. R.; Netemeyer, R. G., \& Garretson, J. A. (1998). A scale for measuring attitude toward private label products and an examination of its psychological and behavioral correlates. Journal of the Academy of Marketing Science, 26, 293-306.

Capon, N.; Farley, J. U.; Hulbert, J., \& Lehmann, D. R. (1992). Profiles of product innovators among large U.S. manufacturers. Management Science, 38, 157-169.

Chi, E. H. (2005). Introducing wearable force sensors in martial arts. IEEE Pervasive Computing, 4(3), 47-53. 
Ko, J. Y.; Chang, Y.; Rhee, Y.; Valacich, J. S.; Hur, Y.; Park, C. (2014). Value-based stakeholder loyalty toward sport technology A case of the electronic body protector and scoring system in taekwondo events. RICYDE. Revista internacional de ciencias del deporte, 35(10), 46-62 http://dx.doi.org/10.5232/ricyde2014.03504

Chu, C., \& Lu, H. (2007). Factors influencing online music purchase intention in Taiwan: An empirical study based on the value-intention framework. Internet Research, 17, 139-155.

Copeland, M. T. (1923). Relation of consumer's buying habits to marketing methods. Harvard Business Review, 1, 282-89.

Davis, F. D. (1989). Perceived usefulness, perceived ease of use, and user acceptance of information technology. MIS Quarterly, 13, 319-340.

Davis, F. D.; Bagozzi, R. P., \& Warshaw, P. R. (1989). User acceptance of computer technology: A comparison of two theoretical models. Management Science, 22, 982-1003.

Davis, F. D.; Bagozzi, R. P., \& Warshaw, P. R. (1992). Extrinsic and intrinsic motivation to use computers in the workplace. Journal of Applied Social Psychology, 22, 1111-1132.

Dodds, W. B.; Monroe, K. B., \& Grewal, D. (1991). Effects of price, brand, and store information on buyers' product evaluations. Journal of Marketing Research, 28, 307-319.

Fishbein, M., \& Ajzen, I. (1975). Belief, attitude, intention and behavior: An introduction to theory and research. Reading, MA: Addison-Wesley.

Fisher, T. (2009). ROI in social media: A look at the arguments. Journal of Database Marketing \& Customer Strategy Management, 16, 189-195.

Gatignon, H., \& Xuereb, J. (1997). Strategic orientation of the firm and new product performance. Journal of Marketing Research, 34, 77-90.

Gefen, D., \& Straub, D. (2000). The relative importance of perceived ease of use in IS adoption: a study of e-commerce adoption. Journal of the Association for Information Systems, 1(8), 1-30.

Hair, J. F.; Black, B.; Babin, B.; Anderson, R. E., \& Tatham, R. L. (2005). Multivariate data analysis. (6th ed.). Upper Saddle River, NJ: Prentice Hall.

Holbrook, M. B. (2006). Consumption experience, customer value, and subjective personal introspection: An illustrative photographic essay. Journal of Business Research, 59, 714-725.

Ingenbleek, P. T. M.; Frambach, R. T., \& Verhallen, T. M. M. (2010). The role of value-informed pricing in market-oriented product innovation management. Journal of Product Innovation Management, 27, 1032-1046.

Johnson, M.; Gustafsson, A.; Andreassen, T. W.; Lervik, L., \& Cha, J. (2001). The evolution and future of national customer satisfaction index models. Journal of Economic Psychology, 22, 217-245. 
Ko, J. Y.; Chang, Y.; Rhee, Y.; Valacich, J. S.; Hur, Y.; Park, C. (2014). Value-based stakeholder loyalty toward sport technology A case of the electronic body protector and scoring system in taekwondo events. RICYDE. Revista internacional de ciencias del deporte, 35(10), 46-62 http://dx.doi.org/10.5232/ricyde2014.03504

Keller, L. K. (1993). Conceptualizing, measuring, and managing customer-based brand

Equity. Journal of Marketing, 57, 1-22.

Kendzierski, D., \& Whitaker, D. J. (1997). The role of self-schema in linking intentions with behavior. Personality and Social Psychology Bulletin, 23, 139-47.

Kim, H.; Chan, H. C., \& Gupta, S. (2007). Value-based adoption of mobile internet: an empirical investigation. Decision Support Systems, 43, 111-126.

Kline, R. B. (2005). Principles and practice of structural equation modeling. (2nd ed.). New York: Guilford.

Ko, Y. J.; Cattani, K.; Chang, Y., \& Hur, Y. (2011). Do spectators and competitors accept the use of scoring technology in Taekwondo competitions? International Journal of Sport Management and Marketing, 9, 238-253.

Knox, S., \& Walker, D. (2001). Measuring and managing brand loyalty. Journal of Strategic Marketing, 9, 111-28.

Lim, H., \& Dubinsky, A. J. (2004). Consumers' perceptions of e-shopping characteristics: An expectancy-value approach. Journal of Services Marketing, 18, 500-513.

Netemeyer, R. G.; Bearden, W. O., \& Sharma, S. (2003). Scaling procedures: Issues and applications. London: SAGE Publications.

Oliver, R. L. (1999). Whence consumer loyalty? Journal of Marketing, 63, 33-44.

Palmgreen, P. (1984). The uses and gratifications approach: a theoretical perspective. In R. N. Bostrom (Ed.), Communication yearbook (Vol. 8, pp. 20-55). Newbury Park, CA: Sage.

Parasuraman, A., \& Grewal, D. (2000). The impact of technology on the quality-value-loyalty chain: A research agenda. Journal of the Academy of Marketing Science, 28, 168-74.

Parks, L., \& Guay, R. P. (2009). Personality, values, and motivation. Personality and Individual Differences, 47, 675-84.

Patterson, P. G., \& Spreng, R. A. (1997). Modeling the relationship between perceived value, satisfaction and repurchase intentions in a business-to-business, services context: an empirical examination. International Journal of Service Industry Management, 8, 414-434.

Petrova, P. K., \& Cialdini, R. B. (2005). Fluency of consumption imagery and the backfire effects of imagery appeals. Journal of Consumer Research, 32, 442-452.

Priester, J. R.; Nayakankuppam, D. ; Fleming, M. A., \& Godek, J. (2004). The A2 SC 2 model: The influence of attitudes and attitude strength on consideration and choice. Journal of Consumer Research, 30, 574-87. 
Ko, J. Y.; Chang, Y.; Rhee, Y.; Valacich, J. S.; Hur, Y.; Park, C. (2014). Value-based stakeholder loyalty toward sport technology A case of the electronic body protector and scoring system in taekwondo events. RICYDE. Revista internacional de ciencias del deporte, 35(10), 46-62 http://dx.doi.org/10.5232/ricyde2014.03504

R Development Core Team (2012). R: a language and environment for statistical computing (Version 2.15.2) [Computer software]. Vienna: R Foundation for Statistical Computing.

Rosseel, Y. (2012). lavaan: An R package for structural equation modeling. Journal of Statistical Software, 48(2), 1-36.

Sánchez-Fernandez, R.,; Iniesta-Bonillo, M. A., \& Holbrook, M. B. (2009). The conceptualisation and measurement of consumer value in services. International Journal of Market Research, 51, 93-113.

Schwartz, S. H. (1994). Are there universal aspects in the structure and contents of human values? Journal of Social Issues, 50(4), 19-45.

Sen, S., \& Bhattacharya, C. B. (2001). Does doing good always lead to doing better? Consumer reactions to corporate social responsibility. Journal of Marketing Research, $38,225-243$.

Sheth, J. N.; Newman, B. I., \& Gross, B. L. (1991). Why we buy what we buy: A theory of consumption values. Journal of Business Research, 22, 159-170.

Smith, R. E., \& Vogt, C. A. (1995). The effects of integrating advertising and negative word-of-mouth communications on message processing and response. Journal of Consumer Psychology, 4, 133-151.

Steenkamp, J. E. M., \& Geyskens, I. (2006). How country characteristics affect the perceived value of web sites. Journal of Marketing, 70, 136-150.

Sweeney, J. C., \& Soutar, G. N. (2001). Consumer perceived value: The development of a multiple item scale. Journal of Retailing, 77, 203-220.

Venkatesh, V. (2000). Determinants of perceived ease of use: Integrating control, intrinsic motivation, and emotion into the technology acceptance model. Information Systems Research, 11, 342-365.

Venkatesh, V., \& Davis, F. D. (2000). A theoretical extension of the technology acceptance model: four longitudinal field studies. Management Science, 46, 186-204.

Yang, Z., \& Peterson, R. T. (2004). Customer perceived value, satisfaction, and loyalty: The role of switching costs. Psychology \& Marketing, 21, 799-822.

Yi, Y. (1990). A critical review of consumer satisfaction. In V. Zeithaml (Ed.), Review of marketing (pp. 68-123). Chicago: American Marketing Association.

Zeithaml, V. (1988). Consumer perceptions of price, quality, and value: A means-end model and synthesis of the evidence. Journal of Marketing, 52, 2-22.

Zhang, X., \& Prybutok, V. R. (2005). A consumer perspective of E-service quality. Engineering Management, 52, 461-477 